\title{
Work-Life Balance of Female University Teachers during COVID-19 Pandemic in Bangladesh
}

\author{
Sangita Basak $^{1^{*}} \quad$ Khaleda Akter ${ }^{2}$ \\ 1.Assistant Professor, Department of Management Studies, Comilla University, Cumilla-3506, Bangladesh. \\ 2.Lecturer, School of Business, Britannia University, Cumilla-3500, Bangladesh. \\ * E-mail of the corresponding author:* sangitamgtcou@gmail.com
}

\begin{abstract}
Throughout the history, the central role of ladies in society has ensured stability, progress and long-run development. Women are the first caretaker of youngsters and elders in each society. In Bangladesh, an oversized portion of economic activities are dole out by women together with social unit and care activities, agriculture, education, industries, banking and repair sectors. This study aims to spot the factors that have an effect on maintaining correct work-life balance of working women (university teachers) in Bangladesh throughout COVID-19 pandemic. To pursue this objective, 210 female teachers from different public and personal universities in Bangladesh have arbitrarily elect. Collected responses have tested with the assistance of assorted applied mathematics tools like reliability and validity checking, multivariate analysis, ANOVA and descriptive analysis. The results has been presented in table. The study finds out a robust impact of Covid-19 pandemic, job satisfaction, flexibility, workplace support, financial assistance and a moderate impact of productivity, support from family and health and safety issues on work-life balance of female university teachers Bangladesh. Covid-19 has greatest impact on job stress, job satisfaction and productivity of female teachers and arises a desire for flexibility, work-place support and work-life balance policy for them. This study revealed that each universities ought to have work-life balance policy, day-care center that is critical to take care of a healthy operating atmosphere for all, which can improve productivity and job satisfaction of academicians.
\end{abstract}

Keywords: Work-Life Balance, Women, Covid-19, University Teachers, Bangladesh.

DOI: $10.7176 / \mathrm{EJBM} / 14-4-07$

Publication date: February $28^{\text {th }} 2022$

\section{Introduction}

In January 2020 World Health Organization (WHO) declared the eruption of a new coronavirus disease, COVID-19, to be a Public Health Emergency of International Concern. World Health Organization expressed that there's a high risk of COVID-19 spreading to different countries around the world. In March 2020, WHO created the assessment that COVID-19 will be characterized as an outbreak (WHO 2020). Consistent with the Organization for Economic Cooperation and Development (OECD), women are notably exposed to the current crisis. They are on the frontlines of the fight against the virus itself, creating up 70th of world attention employees and the maximum amount as 95th of long-run care staff (OECD, 2020). As ladies need to wrestle larger care demands reception, they get less time to develop their skilled life (Orozco M. 2020). Furthermore COVID-19 will increase their domestic burden likewise as their business life vogue has conjointly modified (UN Women2020). Now-a-days, they have to be additional careful concerning their youngsters and relations to stay them safe from coronavirus. Besides there are threats of loss of job, lower financial gain that creates job insecurity and monetary crisis for them. (Carvalho R, Cheung E and Siu P, 2020). In Bangladesh, ladies are taking part and contributory remarkably in our economy. Several evidences on the impact of COVID-19 shows that women's economic and productive lives are negatively poignant throughout COVID-19 pandemic. Such impact already limits women's ability to support themselves and their families (ILO 2020). The challenges women face complex complicated and interconnected. Women's monetary activities could also be hindered by unevenly distributed domestic burdens (Flynn L.2020). Moreover, violence against girls and women are increasing globally because the COVID-19 pandemic combines with economic and social stress. (Human Rights Watch, 2020). According to World Health Organization (WHO 2020), one out of in the girls within the world expertise physical or sexual violence throughout their life and this can be additionally holding true for the coronavirus outbreak. Covid-19 will increase their domestic burden similarly as their career style has additionally modified. Women's monetary activities could also be hindered by unevenly distributed domestic burdens. Moreover, violence against girls and women are increasing globally because the covid-19 pandemic combines with economic and social stress. Now-a-days, they have to be additional careful concerning their kids and members of the family to stay them far from infection of coronavirus. Besides there are threats of loss of job, lower financial gain that creates job insecurity and monetary crisis for them. Several private organizations in Bangladesh aren't paying their workers full regular payment throughout COVID-19 lockdown. Some are sacking their workers to keep up their overhead. These additionally possess monetary and mental stress on female workers particularly once they are the sole earning member of their families. (The Daily Star 2020). 


\subsection{Background of the study}

As of one June 2020, globally, 1.2 billion learners (68.0 per cent of the world's total listed learners) were affected thanks to the education institute closure in one hundred forty four countries, in keeping with UN agency data. Asian nation is not any all completely different. Since seventeen March, all the educational institutes within the country have remained closed. Undeniably, the direct and most immediate impact of the Covid-19 on the education sector is that the loss in learning opportunities. Over 36.0 million students (including seventeen.0 million within the primary) are presently out of college. Minister AHM Mustafa Kamal, in his budget speech within the national parliament on weekday, collectively aforesaid that Covid-19 has essentially caused termination of the regular academic program of around 40 million students across the country. (The Financial Express, May 21, 2021). The gap of educational institutions was unsure from the beginning of the imprisonment so the government initiated an internet category system to attain to achieve students. So, United Nations Children's Fund and additionally the government of Asian nation are in operation on to deliver winning remote learning programs to substantiate the foremost vary of scholars by victimization TV, radio, mobile phone, and on-line platforms (UNICEF, 2020). Besides United Nations Children's Fund, The Ministry of Education (MoE) has to boot helped to develop guides to support teachers for taking the category and minimize the losses of scholars to shun the gap (Alam, 2020).

\subsection{Problem Statement}

COVID-19 is a recently recognized virus and has caused pandemic, it has multiple impact according to environment and circumstances. Women are on the frontlines of the fight against the virus and it has multiple impact on their health, security, personal and professional life, children, self-management and relationship status. Many researchers have studied about the causes of imbalance of work-life of female in several times, several sectors but very few of them have studies about work-life balance of University teachers especially female teachers. This study has fined out the work-life balance of female university teachers working in different private and public universities during Covid-19 in Bangladesh.

\subsection{Objectives of the Study}

The primary concern of this study is to find out the Work-life Balance of female university teachers during COVID-19 pandemic in Bangladesh. The secondary concerns are to find out whether Job Satisfaction, Productivity, Flexibility, Workplace, Financial Assistance and Health and Safety Issues has any impact on Work-Life Balance of Female university teachers in Bangladesh.

\section{Review of Existing Literature}

\subsection{Work-Life Balance}

Fundamentally, work-life balance methods are an important aspect of human resource management, which includes gaining collective and adequate consideration from government, labor employers, and academics. The reason for this is that it is a strong motivator for enhanced structure responsiveness in terms of the implementation and administration of work-life balance. It's also closely linked to balance between the amount of time and energy a person devotes to his or her body and personal endeavors in order to live a happy life. The goal of labor-life balance techniques is to improve stability between the stresses of the job and, as a result, excellent management of life outside the workplace and a diverse work environment. Work-life balance is seen as the most important problem, according to Bird (2006). As for that, it's projected to become one of the most important issues for human resource experts to deal with in the coming decade. Work-life balance is ranked first, according to Kehl (2012) in Industry Week Magazine, while salary is ranked second. Furthermore, a worker who believes he or she has a good work-life balance is considered to be twenty-first more difficult to figure or place effort than workers who perform a lot of job with no balance. According to Patton research (Noe, 2013), seventy-five percent of workers say they don't have enough time to spend with their children, while sixty-one percent believe they don't have enough time to spend with their partner. Job-life balance, according to Lockwood (2003), is a means of managing individual and work responsibilities. The concept of work-life balance is concerned with the outcomes of a person's efforts to strike a balance between competing demands at home and at work. Work-life balance is especially important when institutes need to manage extremely technical professionals because their strong loyalty and commitment are required for the institute's success. It could be a business to meet the needs of the employees (Eshetu, 2016). In other words, it depicts how people fulfill their business and personal commitments in such a way that an overlapping situation is avoided (Konrad \&Mangel, 2000). Furthermore, according to Clark (2000), leveling work and life is the process of achieving an optimal balance between a person's career and their personal life, which includes all of their various associations.

\subsection{COVID-19 Situation}

The COVID-19 pandemic in Bangladesh is part of a worldwide coronavirus sickness 2019 (COVID-19) 
pandemic caused by coronavirus 2 (severe acute metabolism syndrome) (SARS-CoV-2). In March 2020, it was confirmed that the virus had spread to Bangladesh. The country's epidemiology institute, IEDCR, reported the first three cases on March 8, 2020. Since then, the pandemic has spread across the country on a daily basis, and the number of people affected has grown. To protect the people, the administration imposed a "lockdown" across the state from March 23 to May 30 and prepared to take the necessary actions to raise awareness and keep the sickness at bay. The deadline was later pushed back to 30 May 2020. After India and Pakistan, Bangladesh is the third most impacted country in South Asia. According to the World Health Organization, there were 785,194 confirmed cases of COVID-19 in Bangladesh from 3 January 2020 to 21 May 2021, with 12,284 deaths. A total of 9,413,433 vaccination doses have been delivered as of May 3, 2021. Individuals with COVID-19 have reported a wide range of symptoms, ranging from mild symptoms to severe illness, according to the Centers for Disease Control and Prevention (CDC, March 2020). After being exposed to the virus, symptoms may appear 214 days later. COVID-19 is a virus that causes these symptoms in people. Fever or chills, cough, shortness of breath or difficulty breathing are all symptoms of a fever or chills. Fatigue, aches in the muscles or throughout the body Inflammatory illness, headache, new loss of style or smell If you have congestion or a runny nose, Diarrhea, nausea, or vomiting As of 8:46 p.m. on November 2, 2020, there were 46,403,652 verified COVID-19 cases worldwide, with 1,198,569 deaths reported to the World Health Organization by national authorities. The United States, the world's worst-affected country, has reported 9,032,465 (80,379) cases and $228,998(813)$ deaths to WHO, followed by India with 8,229,313 $(45,231)$ cases and France with 49,290 new cases. Brazil came in second with 159,884 (407) deaths, followed by India with 122,607 (496). According to the DGHS press release, there were four hundred ten thousand nine hundred eighty-eight $(410,988)$ COVID-19 confirmed by RTPCR between March 8 and November 2, 2020, with five thousand nine hundred sixty-six $(5,966)$ linked deaths (CFR one.79 percent ). Bangladesh is the world's twenty-first most populous country, accounting for around onefifth of the global COVID-19 illness burden (USAID scenario report-36, 2 November, 2020).

\subsection{Job Satisfaction}

A person's job satisfaction can be defined as a positive mental sensation about his or her work. Job satisfaction instills a favorable attitude in employees, resulting in a positive work environment. Associate in Nursing feeling, a feeling, an attitude, and a matter of perception, job satisfaction is a feeling, a feeling, an attitude, and a matter of perception. It includes the worker's likes and dislikes, as well as internal and exterior desires and desires. Organizations will get more financial benefits once their employees are dedicated. A happy staff is critical to an organization's and its business's success. Dissatisfied employees make businesses dysfunctional, affecting their financial performance. When such employees are left alone, they lose their allegiance to their employers, and as a result, it is difficult to get them to behave in the way that is wanted. Organizations cannot succeed without the efforts and commitment of their employees. Job happiness is critical for retaining and attracting top talent. Because of their total performance, employees who are more satisfied with body pointers have more social control fecundity. Similarly, awards can boost an employee's level of job satisfaction. "Job satisfaction refers to the amount of pleasure or enjoyment derived from one's work. If you are passionate about your career, you will have a high level of job satisfaction. Job happiness is difficult to get if you despise your job intensely" (Draflke M., 2008). A contented employee is more likely to be creative, adaptable, imaginative, and dependable (Ajmir, 2001). Having a good work-life balance benefits both the employee and the manager. Furthermore, job satisfaction is defined as a recompense that employees seek as a result of economic mobility on an individual basis from employees' profits (Mustapha 2013). Job satisfaction, according to Choreographer and Decide (2013), is defined as a good attitude toward a specific job, followed by an assessment of its characteristics. In other words, UN agency employees have a high level of job satisfaction and a good attitude about their employment. Employees who are dissatisfied with their jobs, on the other hand, are more likely to have a negative attitude toward their work. The link between job satisfaction and worker performance, according to Pugno and Depedri (2009), is clear. According to their findings, job satisfaction is inextricably linked to worker performance.

\subsection{Productivity}

Employee's productivity in any organization could be a key space within the work surroundings. It assists the business to develop the aptitude of the human resources within the system to be competent. Productivity means that the end results of an activity of someone or organization. This disclosed that the success of any organization mostly rests on the productivity of workers among the system. It's thus, necessary for managers at the helm of business affairs to adopt the approach that may result in employee's retention. The essence of leveling each personal and work life is to encourage healthy atmosphere that may guarantee loyalty of the workers and secure high level of productivity. According to Chris and Awonusi (2004), confirmed productivity as a method of measurement and scrutinizing the responsibilities of workers within the organization. Therefore, a company needed an increase level of productivity of its employee's, so as for the declared goals to be achieved (Dreher, 2003). A business lexicon explains worker productivity as the job-related events projected of a worker and to 
what extent those activities were enforced. Totally different research is in support to the actual fact that a personal can contribute to the event of their organizations once they get pleasure from a work life balance (Oswald, 2012). Consequently, the mix of flexibility of work schedule beside job angle has been connected to extend in structure commitment from workers, satisfaction from the task and above all reduction in turnover intention (Lewis \& Gambles, 2007). Productivity is that the ability to hold out a duty or job that sustains the gain of the organization. It's a comparison of the quantity of effectiveness (ratio of inputs and outputs) that results from a precise level of price related to that effectiveness (Sukal 2009). Productivity indicates the extent to that a firm's human capital is with efficiency making output (Guthrie 2001, Fransman 2015).

\subsection{Flexibility}

Costa, Sartori, and Akerstedt (2006) define flexibility as the degree of individual discretion and autonomy. Flexible work practices are classified as office-based practices and flexi-place practices (Grobler \& de Bruyn2011), as well as flexitime and flexi-place practices (Munsch, Ridgeway \& Williams 2014). Flexible work options will include contingent employment, contract work, and just-in-time staffing, according to Kelly, Moen, and Tranby (2011). Flexible work options will include contingent work, contract work, and just-in-time staffing. The extent to which workers experience flexible working hours necessitates a substantiative structure culture (Galea, Houkes, \& Diamond State Rijk 2014), and it is critical that management recognizes that workers go through various phases throughout their careers, and their specific needs will change (Fransman 2015). According to Moen et al. (2011), an organizational policy effort that increases worker work-time management and adaptability will reduce turnover. Employers benefit from increased competitive edge, higher productivity, and the acquisition and retention of top talent, while employees benefit from enhanced employee morale and quality of life, as well as fewer unplanned absences (Grobler \& de Bruyn 2011). Most businesses use flexible work methods to improve their operational efficiency (Appiah-Mfodwa et al. 2000). Work that is versatile has the ability to help both people and companies by promoting positive work attitudes such as structure dedication, motivation, and job satisfaction, as well as high levels of job performance (Fransman 2015; Leslie et al. 2012; Nadeem \& Henry 2003).

\subsection{Workplace Support}

An individual will actively seek a career and position that will contribute significantly to achieving a healthy Work-Life Balance. Organizations will also play an important role in supporting individual individuals to achieve Work-Life Balance. Formal leave policies, for example, that actively encourage workers to take time off when needed can help employees achieve WLB while also emphasizing the need of maintaining personal health, family support, and psychological well-being. Organizations will be able to attract, recruit, and retain workers if they have family-friendly policies and a culture of family support (Carless \& Wintle, 2007; Lee \& Hong, 2011). An extensive literature has evolved that discusses what firms should do to create an environment or culture that allows employees to balance their professional and personal lives. Senior management and human resource professionals often view such measures as a critical component of an organization's overall diversity strategy and a requirement for being competitive in the business world (Michielsens, Bingham, \& Clarke, 2014). In terms of work-life balance, experts have also emphasized that a corporate certification work culture could be a significant factor (Appelbaum, Bailey, Berg, \& Kalleberg, 2005). A certory culture means that an organization's overall structure is considerate of employees' family needs and does not require work to take precedence over family. A certified workplace culture could also be defined as the availability of formal flexible planning regulations that function from a geographical standpoint, such as shift start and end times that are flexible on a daily basis. . Furthermore, some experts have stated that top-down assistance in organizations is critical for balancing worklife responsibilities (Behson, 2005; Mennino et al., 2005; Secret \& Sprang, 2001). Previous work-life research have shown that the perception of having social support at work is more important than the formal presence of family-friendly policies in promoting positive work-life outcomes (Allen, 2001; Ayman \& Antani, 2008; Thompson \& Prottas, 2006). Social support can also be defined as 'the ease with which one can serve one's relationships, as well as the quality of those ties' (Leavy, 1983). Workers form such social bonds with alternative structure members in the same way they do with their direct bosses in the workplace. As a result, we tend to think of geographical point support as a composite concept that includes support from a variety of sources. As a result, we prefer to think of geographical point assistance as a composite concept that includes help from the organization as a whole, as well as direct supervisors. It has been demonstrated that implementing familyfriendly initiatives is a required but insufficient prerequisite for achieving positive work-life outcomes (Allen, 2001; Lapierre \& Allen, 2006). This is because if a company isn't seen as trustworthy, employees will be less likely to use family-friendly programs to avoid the bad consequences, such as career stagnation, that are frequently associated with the usage of such edges (Kossek et al., 2011; Lobel \& Kossek, 1996). WLB will be facilitated by a variety of measures, including official policies that provide structure support for families, child care, and various work schedules(Facer \& Wadsworth, 2008; Saltzstein, Ting, \& Saltzstein, 2001). 


\subsection{Support from Family}

Instrumental family social support refers to the various concrete types of assistance that family members can provide one another to aid them with their everyday chores, whereas emotional family support refers to the things that family members do to make others feel cared for (Adams, King, \& King, 1996). Many studies have demonstrated the importance of family social support in achieving positive work and nonwork outcomes, particularly in relation to work-family facilitation (Aryee et al., 2005), work-family conflict (Griggs, Casper, \& Eby, 2013; Wallace, 2005), effective coping with life stressors, and improved performance in all areas of life (ten Brummelhuis, Haar, \& Roche, 2014). Family support has been linked to better levels of subjective wellbeing and life satisfaction in studies conducted in numerous nations. In adolescents and youth, there is more contentment with food-related life and more satisfaction with family life. Strazdins et al. (2006) discovered that irregular work schedules contributed to depressive symptoms in seniors, which had a negative impact on their children's well-being. Lawson et al. (2014) recently discovered that favorable job experiences for moms lead to reduced levels of negative moods at work, resulting in greater rumored levels of well-being in teenagers. Positive work-related experiences in mothers were both directly and indirectly associated to children's life happiness, according to Mauno et al. (2018). Similarly, other studies claim that a parent's job is linked to conflict with their children, and that work stress has a negative impact on the quality of family interactions. According to certain studies, employed mothers, as well as twin jobholder households with a poor work-life balance, are linked to less healthier food surroundings, less encouragement for their children to make healthy food choices, and fewer frequent family meals (Bauer, K.W.; Hearst, 2012).

\subsection{Financial Assistance}

Throughout this study, the phrases "economic well-being" and "monetary well-being" are used interchangeably. Economic wellbeing will be proxied by economic well-being and financial well-being. Economic well-being has grown from a simple sense of contentment or general satisfaction with one's material or financial situation to a complex understanding of both the material and nonmaterial aspects of one's financial situation. Satisfaction with financial gain and savings, awareness of opportunities, ability to make ends meet, sense of material stability, and sense of fairness of the reward distribution system are all part of the complex perspective (Strumpel, 1976). Low-income households' financial suffering may be exacerbated by a lack of sufficient incomes. Lowincome households report higher levels of economic stress and more frequent engagement in harmful coping strategies than their higher-income counterparts (American Psychological Association, 2015). Employees' and workplaces' financial distress has also been reported in studies. According to a 2015 financial finesse research, about a quarter of workers regarded their money stress as extreme or overwhelming, with 84 blaming it on a lack of financial management (Robertson, Ward, \& Davidson, 2015). Human resource specialists said those employees were more likely than others to request a loan or a hardship withdrawal from their pre-determined contribution plan(Society for Human Resource Management, 2014a). EFWPs have recently evolved as a distinct employee-benefit model that represents a paradigm shift in both the goal and content of benefits. As firms develop more comprehensive approaches to boosting employees' financial well-being, the traditional role of workplace edges is changing. Within the field, however, the term EFWP has been defined in a variety of ways. It's a term used to describe a variety of products and services provided by businesses, which may or may not promote employees' financial well-being. It usually relates solely to education on employee retirement and insurance benefits provided by large suppliers. Williams (1983) defined economic well-being as a combination of material and non-material dimensions of one's financial situation. She included cash financial gain, actual or complete financial gain, agreement regarding distribution, and psychological financial gain or felt adequacy of financial gain as freelance variables to detect economic well-being. Economic well-being is defined by Fergusson, Horwood, and Beautrais (1981) as the number of economic inputs, such as cash gain and assets.

\subsection{Health and Safety Issue}

A lack of work-life balance is regarded as a work-related factor. Previous studies have found a link between work-life balance and stress reactions such as higher blood pressure, heart rate, and hydrocortisone levels. According to studies, women are more vulnerable to the strains of work-life balance than males. Feminist experts have discovered that the majority of women are still responsible for their children and household chores, and that most women work "second shift" at home (Barnett, 2004; Barnett \& Hyde, 2001; Hochschild, 1989). It's been observed that women are traditionally more likely to identify with the roles of mother, wife, friend, and daughter, i.e., with caring and social interactions, whereas males are more likely to identify with their careers (Chodorow, 1978; Gilligan, 1982; Thoits, 1986). According to Fapohunda (2014), the primary characteristic of work-life balance is the amount of time spent at work. Excessive working hours, according to academic data, harms employees' health, jeopardizes their safety, and increases stress. For example, chronic work-stress, uneven and longer shifts, and substance abuse all contribute to major cardio-vascular disorders like strokes and heart attacks (Burke and Cooper, 2008; Chandola et al., 2008; Knuttson et al., 1986 cited in Fagan et al., 2011). The 
difficulties that girls encounter are numerous and diverse. Unevenly distributed domestic duties may also impede women's financial efforts (Flynn L.2020). Furthermore, as the COVID-19 epidemic combines with economic and societal stress, violence against women and girls is on the rise around the world. (Human Rights Watch, 2020). consistent with World Health Organization (WHO 2020), one out of 3 girls within the world experience physical or sexual violence throughout their lifespan and this is often conjointly holding true for the coronavirus outbreak.

\section{Methodology}

The research is descriptive in nature. Descriptive analysis refers to the transformation of raw data into a form that will make them easy to understand and interprets (M. A. S. Akanda, 2019). This research has conducted among the female university teachers working in different public and private universities in Bangladesh.

\subsection{Sampling Design}

Sampling, according to Kothari (2011), is the process of picking a sample from a population. Random sampling is a sampling strategy in which every member of the population has an equal probability of being included in the sample (M.A.S.Akanda, 2019). Two hundred and ten (210) female instructors were randomly selected as a sample from ten public and private universities in Bangladesh. It is not possible to work on the entire population due to time constraints.

\subsection{Data Collection Process}

The study is based on both primary and secondary sources of information. Primary data was acquired by surveying female university teachers working in both public and private universities in Bangladesh. To collect primary data, secession used both a questionnaire and an interview. Relevant literature, books, articles, newspapers, and magazines will be collected for secondary research. Monthly updates for COVID-19-related data will be collected from authorized sources.

\subsubsection{Questionnaire Design}

A questionnaire is a set of questions that are asked of people in order to gather statistically relevant data on a specific topic. The measurements will be created through a series of scale development processes. All items will be graded on a 5 -point Likert scale ( $1=$ strongly disagree, $2=$ disagree, $3=$ neutral, $4=$ agree, and $5=$ strongly agree). 3.2.2. Interviews

An interview, according to Scott and others (2017), is a planned exchange of ideas, questions, and dialogue between two or more people. Structured Interview will be my interview type. Some questions may be clarified by the interviewer (M. Easwaramoorthy \& F. Zarinpoush 2019). A total of 50 respondents from 20 different private and governmental universities in Bangladesh will be interviewed.

\subsection{Data Interpretation Technique}

In SPSS 25 version, descriptive statistics such as frequency distribution (mean, median, mode, standard deviation, and variance), reliability and validity checking, correlation and regression analysis, ANOVA, and hypothesis test are used to analyze the data collected from survey operations.

\section{Results and Discussion}

\subsection{Reliability and Validity of data}

Reliability refers to the consistency of set of items in measuring the study variables (Cooper \& Schinder, 2001). Cronbach's alpha is commonly used method to measure the reliability or internal consistency that is, how closely related a set of items are as a group (Cooper \& Schinder, 2001). The satisfactory value in Cronbach's alpha is required to be more than 0.60 to be reliable (Malhotra, 2002). In this study, Cronbach's alpha is .880 (Table-1), which indicates a satisfactory level of internal consistency for the scale.

\section{Table-1 Reliability Statistics}

\begin{tabular}{|c|r|r|}
\hline \multicolumn{1}{|c|}{ Cronbach's Alpha $^{\mathrm{a}}$} & $\begin{array}{c}\text { Cronbach's Alpha Based } \\
\text { on Standardized Items }\end{array}$ & N of Items \\
\hline .880 & .880 & 8 \\
\hline
\end{tabular}

\subsection{Regression Analysis}

\subsubsection{Model Summary}

The value of R Square (0.850) and R (0.922) shows that there is strong association between the set of independent variables and the dependent variable with the standard error of 0.403 (Table-4). In additions, the Table-2 implies that the work-life balance of female university teachers in Bangladesh is $85 \%$ dependent on 
COVID 19, Job Satisfaction, Productivity, Flexibility, Workplace Support, Family Support, Financial Assistance and Health and Safety Issues. The rest only $15 \%$ is dependent on some others factors that are not considered by the researcher in this study.

Table-2: Regression Model Summary

\begin{tabular}{|r|r|r|r|r|}
\hline Model & R & R Square & Adjusted R Square & Std. Error of the Estimate \\
\hline 1 & $.922^{\mathrm{a}}$ & .850 & .829 & .40320 \\
\hline
\end{tabular}

\subsection{ANOVA test}

The $\mathrm{F}$ value of the test for the data is 38.230 . The p-value associated with this $\mathrm{F}$ value which is .000 which is lower than the alpha value 0.05 (Table-3). In additions, The Table-4 implies that there is significant influence of these independent variables on the dependent variable and the model applied is significantly good to predict the dependent variable.

Table-3 ANOVA

\begin{tabular}{|ll|r|r|r|r|}
\hline Model & & Sum of Squares & Mean Square & F & \multicolumn{1}{c|}{ Sig. } \\
\hline 1 & Regression & 18.765 & 5.254 & 38.230 & $.000^{\mathrm{a}}$ \\
& Residual & 91.197 & .137 & & \\
& Total & 109.962 & & & \\
\hline
\end{tabular}

Source: SPSS output

\subsection{Regression Coefficients}

With a standard error of 0.403 , R Square $(0.850)$ and R $(0.922)$ indicate a strong relationship between the set of independent factors and the dependent variable (Table-4). Furthermore, Table-2 shows that COVID 19, Job Satisfaction, Productivity, Flexibility, Workplace Support, Family Support, Financial Assistance, and Health and Safety Issues are all important factors in the work-life balance of female university instructors in Bangladesh. Only $15 \%$ is determined by other characteristics that were not taken into account by the researcher in this study.

The application of the beta-values in the multiple regression model equation (YCCT $=\beta 0+\beta 1 \mathrm{v} 1+\beta 2 \mathrm{v} 2+$ $\beta 3 \mathrm{v} 3+\beta 4 \mathrm{v} 4+\beta 4 \mathrm{v} 5+\beta 4 \mathrm{v} 6+\beta 4 \mathrm{v} 7+\beta 4 \mathrm{v} 8$ Or, $=.194+.359+.763+.875+.229+.279+.435+.262+.185)$ interprets this model to mean that for every increase of one unit in v1, assuming the effects of v2 to v8 be held constant, factors affecting work-life balance of female university teachers in Bangladesh during Covid-19 pandemic would increase by 0.289 . Likewise, should the effects of other components be held constant, a single unit increase in v2 would result in a 0.334 increase in factors affecting work-life balance of female teachers in Bangladesh during Covid-19 pandemic. Similarly, being other components held constant a single unit increase in v3 to v8 would lead to a $.542, .210, .295, .140, .222$ and .169 increase respectively in the factors affecting worklife balance of female university teachers in Bangladesh during Covid-19 pandemic.

The beta values in Table 4 can be used to determine the relative relevance of each predictor or independent variable to the model because they are standardized versions of the b-values and are directly comparable. In other words, the beta coefficients might be used to explain the relative relevance of the 8 dimensions or components (v1 to v8, i.e., independent variables) in influencing the work-life balance of female university teachers in Bangladesh during the Covid-19 epidemic. 
Table-4 Coefficients ${ }^{\mathrm{a}}$

\begin{tabular}{|c|c|c|c|c|c|}
\hline \multirow[b]{2}{*}{ Model } & \multicolumn{2}{|c|}{ Unstandardized Coefficients } & \multirow{2}{*}{$\frac{\text { Standardized Coefficients }}{\text { Beta }}$} & \multirow[b]{2}{*}{$\mathrm{T}$} & \multirow[b]{2}{*}{ Sig. } \\
\hline & B & Std. Error & & & \\
\hline 1 (Constant) & .194 & .268 & & .725 & .471 \\
\hline Covid 19 pandemic (v1) & .359 & .056 & .28 & 8.529 & .000 \\
\hline Job satisfaction (v2) & .763 & .122 & $.3 ?$ & 8.390 & .020 \\
\hline Productivity (v3) & .875 & .218 & .5 & 11.009 & .000 \\
\hline Flexibility (v4) & .229 & .079 & .21 & 2.894 & .005 \\
\hline Workplace support (v5) & 279 & .100 & .25 & 2.788 & .007 \\
\hline Support from family (v6) & .435 & .162 & .12 & 3.188 & .033 \\
\hline Financial assistance (v7) & .262 & .074 & .22 & 3.687 & .000 \\
\hline Health and safety issues (v8) & .185 & .089 & .16 & 2.202 & .041 \\
\hline
\end{tabular}

Source: SPSS output

a. Dependent Variable: Work-life balance of female university teachers

When it comes to the relative relevance of the 8 WLB dimensions, v3: (Beta=0.542) is the most important, followed by v3: $($ Beta=0.334), v5: $($ Beta=0.295), v1: $($ Beta=0.289), v7: $($ Beta=0.222), v4: $(B e t a=0.210), v 8$ : $(B e t a=0.169)$, and v6: $(B e t=0.140)$. Because there are multiple predictors (independent variables), the magnitude of the t-value has been used in conjunction with the significance to assess the overall contribution to the model. According to the decision rule "the bigger the t-value, the greater the contribution of the predictor," v3: $(t=11.009)$ is the most significant predictor, followed by $v 1$ : $(t=8.529), v 2$ : $(t=8.390), v 7$ : $(t=3.687), v 6$ : $(\mathrm{t}=3.118), \mathrm{v} 4:(\mathrm{t}=2.894), \mathrm{v} 5:(\mathrm{t}=2.788)$, and $\mathrm{v} 8:(\mathrm{t}=2.202)$ all of these factors affecting the work-life balance of female university lecturers in Bangladesh during the Covid-19 pandemic are significant predictors or independent variables. In this regard, it can also be deduced from the t-values that $\mathrm{v} 3$ has a bigger impact on the outcome (i.e., WLB) than v1, v2, v7, v6, v4, v5, and v8.

In conclusion, all of the underlying qualities are favorable and, as a result, noteworthy. As indicated by the above-mentioned R, R square, and Adjusted R2, F ratio, Beta, and $\mathrm{t}$ values, the regression model obtained a sufficient level of goodness-of-fit in predicting the variance of WLB in relation to the 8 predictors or independent variables. In other words, during the Covid-19 pandemic in Bangladesh, at least one of the eight predictors or independent factors is significant in influencing the work-life balance of female university teachers.

\section{Findings and Recommendations}

Maintaining a healthy work-life balance is not just the duty of any organization; rather, it is a collaborative effort involving organizations, families, and other stakeholders. In this study, we attempted to determine the current state of female faculty work-life balance in several public and private universities in Bangladesh. The most noteworthy findings, along with some recommendations, are explained here.

Female university professors have a difficult difficulties handling their time and keeping work hours while working from home. In this pandemic, all colleges are offering online education, where teachers can attend courses and participate in other course-related activities from the comfort of their own homes. When they are at home, they are responsible for a variety of household tasks including as cooking, cleaning, childcare, and other responsibilities, and the covid-19 pandemic has added to their labor. It's tough to find a designated time slot for official work at home, so they'll need to make a detailed schedule of their daily activities so that they can devote some time to classes, student counseling, research, and other academic and official tasks.

Women's careers can sometimes cause a clash between their personal and professional lives. Teachers at many private colleges are required to keep office hours, have a large course load, and are not always given leave when it is needed. On the other side, they have so many responsibilities at home that it is difficult for them to focus on their careers, higher education, research, and so on. Working women in many families are required to perform all domestic responsibilities as if they were housewives, with no assistance from their spouses or other family members. This is also true in the case of female professors at public universities. Universities and departments must create a flexible and collaborative working environment for their employees, particularly female employees.

Childcare is a major concern for all mothers, particularly those who work. Despite the fact that women are entitled to six months of maternity leave, this is insufficient for effectively raising a child. Children under the age of two require their moms at all times. Only a few public and private institutions have recently begun to provide childcare for their staff. A day-care service should be offered by the organization. If universities can provide a 
daycare center on campus, female employees will be relieved of their fear about having children, and they will be able to focus fully on their classes, increasing their productivity and job happiness.

In most Bangladeshi universities, there is no well-established Work-Life Balance policy. Employees can better balance their personal and professional lives with the support of a well-established Work-Life Balance policy. They have the potential to be more productive and effective. Some respondents claim that they do not receive equal treatment at work, blaming it on politics, grouping, and favoritisms. Every company should take the initiative to create a Work-Life Balance policy that is aligned with the company's goals and maintain a healthy atmosphere where all employees, regardless of gender, have equal access to resources and opportunity to grow and thrive.

In Bangladesh, online classes are a relatively new addition to the education industry. Although several universities (National University and Bangladesh Open University) have been offering distant learning for some time, we are still relatively new to online education. It was simple for educational institutions to take classes on an ad hoc basis via the internet. However, because to the pandemic, this platform became the only means to conduct large-group classes. Teachers have not received any training or technical assistance from the university, the UGC, or any other agency, and they are having difficulty conducting online classes (technical, material, techniques, and resources). It's past time for teachers to receive training and technical support in order to conduct online classes. Universities, the UGC, and the Ministry of Education should provide basic resources such as laptops, internet access, and access to an online library.

\section{Conclusion}

Fundamentally, work-life balance methods are an important aspect of human resource management, which includes acquiring collective and proper consideration from the government, employers, and researchers. The reason for this is that it is a strong motivator for enhanced structural responsiveness in terms of application and administration of a healthy work-life balance. It's also closely linked to balance between the amount of time and energy a person devotes to his or her body and personal endeavors in order to live a happy life. The goal of work-life balance techniques is to improve balance between the stresses of the job and, as a result, excellent management of life outside the office and a diverse work environment. The key to a working woman's social status is, first and foremost, in her own hands. At home and at work, women need to be more aggressive and conscious of their own rights. Women's empowerment will not be achieved unless women decide to speak out against their exploitation, whether on an economic, social, or sexual basis. The family and society are two important institutions that can work together to improve the status of working women. The lady who works outside the home needs help from her husband and other family members. They must divide household tasks in order for her to be able to apply her skills outside of the home.

\section{References}

Adams, G. A., King, L. A., \& King, D. W., (1996). Relationships of job and family involvement, family social support, and work-family conflict with job and life satisfaction. Journal of Applied Psychology, 81, pp.411-420.

Ajmer (2001). The effect of personal characteristics on job satisfaction: A study among male managers in the Kuwaiti oil industry. International journal of Commerce and Management, 11(3), pp.91-110.

Allen, T. D. (2001). Family-supportive work environments: The role of organizational perceptions. Journal of Vocational Behavior, 58, pp.414-435.

Allis, P. \& O’Driscoll, M. (2008). Positive effects of non-work-to-work facilitation on well-being in work, family and personal domains. Journal of Managerial Psychology, 23(3), pp.273-291

Amstad, F., Meier, L., Fasel, U., Elfering, A. \& Semmer, N. (2011). A Meta-Analysis of Work-Family Conflict and Various Outcomes with a Special Emphasis on Cross-Domain versus Matching-Domain Relations. Journal of Occupational Health Psychology, 16, pp.151-169.

Anwar, J., Hasnu, S.A.F. \& Janjua, S.Y. (2013). Work life balance: what organizations should do to create balance? World Applied Sciences Journal, 24(10), pp.1348-1354.

Appelbaum, E., Bailey, E.,Berg, P.,\& Kalleberg, A., (2005). Organizations and the intersection of work and family. In S. Ackroyd, R. Batt, and P. S. Tolbert (Ed.), The Oxford handbook of work and organization (pp. 52-73). London: Oxford University Press.

Aryee, S., Srinivas, E. S., \& Tan, H. H. (2005). Rhythms of life: Antecedents and outcomes of work-family balance in employed parents. Journal of Applied Psychology, 90, pp.132-146.

Ayman, R., \& Antani, A. (2008). Social support and work- family conflict. In K. Korabik, D. S. Lero, and D. L. Whitehead (Eds.), Handbook of work-family integration (pp. 287-304), Amsterdam: Academic Press.

Barnett, R.C. (2004). Women and Multiple Roles: Myths and Reality. Harvard Review Psychiatry, 12(3), pp. $158-164$.

Barnett, R.C. \& Hyde, J.S. (2001). Women, Men, Work and Family: An Expansionist Theory. The American 
Psychologist, 56(10), pp. 781-796.

Bauer, K.W.,Hearst, M.O., Escoto, K., Berge, J.M., \& Neumark, S.D. (2012). Parental employment and workfamily stress: Associations with family food environments. Social. Med., 75, pp.496-504.

Behson, S. J. (2005). The relative contribution of formal informal organizational work-family support. Journal of Vocational Behavior, 66(3), pp.487-500.

Beutell, N. \& College, I. (2010). The Causes and Consequences of Work-Family Synergy: An Empirical Study in the United States. International Journal of Management, 27, pp. 650-664.

Bird, J. (2006). Work - life balance: Doing it right and avoiding the pitfalls. Employment Relations Today, 33(3), pp.21-30.

Carless, S. A., \& Wintle, J. (2007). Applicant attraction: The role of recruiter function, work-life balance policies and career salience. International Journal of Selection and Assessment, 15, pp.394-404.

Clark, S. C. (2000). Work/family border theory: A new theory of work/family balance. Human relations, 53(6), pp.747-770. First Published June 1, 2000 Research Article https://doi.org/10.1177/0018726700536001

Coomber, B., \& Barriball, K. L. (2007). Impact of job satisfaction components on intent to leave and turnover for hospital-based nurses: a review of the research literature. International journal of nursing studies, 44(2), pp. 297-314.

COVID-19: Thailand to require all travelers to obtain health certificate for entry from Mar 22, Channel News Asia, 20 March 2020.

Doble N., \& Supriya M. V. (2010). Gender Differences in the Perception of Work-Life Balance.Econ Papers Management 2010, 5(4), pp.331-342.

Draflke Micheal. (2008), "The Human side of Organization”, 9th edition, Prentice Hall of India Ltd, pp.300-335.

Dreher, G.F. (2003). The effects of work life programs on female leadership at the top. Journal of human relations, 40(2), pp.541-560.

Eshetu, G. (2016). Practices and Challenges of Human Resource Management in Major General MulugetBuli Technical College.

Facer, R. L., \& Wadsworth, L. L. (2008). Alternative work schedules and work-family balance: A research note. Review of Public Personnel Administration, 28, pp.166-177.

Flynn L., Laura A. \& Harshika G. (2020) .Seven Key Issues Affecting Women and Girls during the COVID-19 Pandemic_-And What You can do about them. https://www.fsg.org/blog/seven-key-issues-affectingwomen-and-girls-during-COVID-19-pandemic.

Fransman, E.I. (2015). Determining the impact of flexible work hours on women employed in a higher education institution', Unpublished MBA dissertation, North-West University, Potchefstroom.

Goyal K.A., \& Agrawel, A. (2015). Issues and Challenges of Work Life Balance in Banking Industry of India. Pacific Business Review International, 8(5), November 2015.

Griggs, T. L., Casper, W. J., \& Eby, L. T. (2013). Work, family and community support as predictors of workfamily conflict: A study of low-income workers. Journal of Vocational Behavior, 82, pp.59-68.

Grobler, P.A. \& De Bruyn, A.J., (2011). Flexible work practices (FWP): An effective instrument in the retention of talent: A survey of selected JSE-listed companies. South African Journal of Business Management, 42(4), pp.63-78.

Grobler, P.A. \& De Bruyn, A.J., 2011, 'Flexible work practices (FWP): An effective instrument in the retention of talent: A survey of selected JSE-listed companies', South African Journal of Business Management 42(4), pp.63-78.

Human Rights Dimensions of COVID-19 Response, Human Rights Watch, 19 March 2020.

International Labour Organization (18 March 2020), 'Almost 25 million jobs could be lost worldwide as a result of COVID-19', says ILO, 18 March 2020.

Mahmud, R.A. et al. (2019).Women's Preferences for Maternal Healthcare Services in Bangladesh: Evidence from a Discrete Choice Experiment. Journal of Clinical Medicine, 8(2),pp.132, doi: 10.3390/jcm8020132

Kapikiran,,S. (2013).Loneliness and life satisfaction in turkish early adolescents: The mediating role of selfesteem and social support. Soc. Indic. Res. 2013, 111, pp.617-632.

Kehl, T, (2012). Key strategies to achieving a work-life balance. Industry Week, Magazine. 12 Key strategies to achieving a work-life balance.

Kelly, E.L., Moen, P.\& Tranby, E., (2011). Changing workplaces to reduce work-family conflict: Schedule control in a white-collar organization. American Sociological Review 76(2), pp.256-290.

Konrad, A. M. \& Mangel, R. (2000). The impact of work-life programs on firm productivity. Strategic Management Journal, pp.1225-1237.

Kumari L.(2012). Employees' Perception on Work Life Balance and its Relation with Job Satisfaction in Indian Public Sector Banks. International Journal of Engineering and Management, IJEMR - February 2012, 2(2).

Lapierre, L. M. \& Allen, T. D. (2006). Work-supportive family, family-supportive supervision, use of organizational benefits, and problem-focused coping: Implications for work-family conflict and employee 
well-being. Journal of Occupational Health Psychology, 11, pp.169-181.

Lawson, K.M., Davis, K.D., McHale, S.M., Hammer, L.B., \& Buxton, O.M. Daily positive spillover and crossover from mothers work to youth health. J. Fam. Psychol. 2014, 28, pp.897-907.

Lazar, I., Osoian, C., and Ratiu, P. (2010), 'The role of work-life balance practices in order to improve organizational performance', European Research Studies Journal, 13(1), pp. 201-214.

Leavy, R. L. (1983). Social support and psychological disorder: A review. Journal of Community Psychology, $11, \mathrm{pp} .3-21$.

Lee, S. Y. \& Hong, J. H. (2011). Does family-friendly policy matter? Testing its impact on turnover and performance. Public Administration Review, 71, pp.870-879.

Leslie, L.M., Manchester, C.F., Park, T. \& Mehng, S.I., (2012). Flexible work practices: A source of career premiums or penalties?. Academy of Management Journal, 55(6), pp.1407-1428.

Lewis, S., Rapoport, R. and Gambles, R. (2007). The constraints of a work life balance approach: an international perspective. The international journal of human resource, 18(3), pp.360-373.

Lobel, S. A., \& Kossek, E. E. (1996). Human resource strategies to support diversity in work and personal lifestyles: Beyond the 'family friendly' organization. In E. E. Kossek and S. A. Lobel (Eds.), Managing diversity: Human resource strategies for transforming the Workplace, Cambridge, MA: Blackwell, pp.221243

Lockwood, N. R. (2003). Work/life balance: Challenges and solutions. HR Magazine, 48(6), pp.1-1.

M. Tasnim et al. (2017). Work-Life Balance: Reality Check for the Working Women of Bangladesh. .Journal of Human Resource and Sustainability Studies, 5, pp.75-86.

Mauno, S., Hirvonen, R., \& Kiuru, N. Children's life satisfaction: The roles of mothers' work engagement and recovery from work. J. Happiness Stud. 2018, 19, pp.1373-1393.

Mazerolle \& Barrett (2018).Work-Life Balance in Higher Education for Women: Perspectives of Athletic Training Faculty. Athletic Training Education Journal, 13 (3), pp. 248-258.

Moen, P., Kelly, E.L., Tranby, E. \& Huang, Q., (2011). 'Changing work, changing health: Can real work-time flexibility promote health behaviors and well-being? .Work and Health 52(4), pp.404-429.

Munsch,C.L., Ridgeway,C.L. \& Williams, J.C., (2014). Pluralistic ignorance and the flexibility bias: Understanding and mitigating flextime and flex place bias at work. Work and Occupations (WOX), https://doi.org/10.1177/0730888413515894.

Monsivais, P., Aggarwal, A., \& Drewnowski, A., (2014). Time spent on home food preparation and indicators of Healthy Eating. American Journal of Preventive Medicine, 47(6), DOI:10.1016/j.amepre.2014.07.033

Murthy, N.M., \& Shastri, S. (2015), 'A qualitative study on work life balance of employees working in private sector', International Journal of Recent Scientific Research, 6(7), pp. 5160-5167.

Mustapha, N. (2013). The influence of financial reward on job satisfaction among academic staffs at public universities in Kelantan, Malaysia. International Journal of Business and Social Science, 4(3).

Nadeem, S. \& Henry.C., (2003). Power dynamics in the long-term development of employee-friendly flexible working. Women in Management Review, 18(1/2), pp.32-49.

Neumark-Sztainer, D., MacLehose, R.,Loth, K.,Fulkerson, J.A.,Eisenberg, M.E., \& Berge, J.( 2014) . What's for dinner? Types of food served at family dinner differ across parent and family characteristics. Public Health Nutr., 17(1), pp.145-155. DOI: 10.1017/S1368980012004594

Noah, Y., \& Steve, M. (2012). Work environment and job attitude among employees in a Nigerian work organization. Journal of Sustainable Society, 1(2), pp.36-43.

Noe, R. (2013). Employee training and Development. 6th edition. Singapore. McGraw Hill.

Orozco, M. (2020). Migrants and the Impact of the COVID-19 Pandemic on Remittances', The Dialogue. Available at: https://www. thedialogue.org/analysis/migrants-and-impacts-of-the-covid- 19-pandemic-onremittances/

P.V Gouri Prabha (2019), 'Challenges And Problems of A Working Woman' International Journal of Innovative Research and Advanced Studies (IJIRAS), 6(5).

Pugno, M., \& Depedri, S. (2010). Job performance and job satisfaction: an integrated survey. Economiapolitica, 27(1), pp.175-210.

Purohit M. (2013). A Comparative Study of Work Life Balance In Various Industrial Sectors In Pune Region. International Journal of Marketing, Financial Services and Management Research, 2(3).

Robbins, S., \&Judge, T. (2013). Organizational Behaviour. England: Pearson Education.

Saltzstein, A. L., Ting, Y., \& Saltzstein, G. H. (2001). Work-family balance and job satisfaction: The impact of family-friendly policies on attitudes of federal government employees. Public Administration Review, 61, pp.452-467.

Schnettler, B., Lobos, G., Miranda-Zapata, E., Denegri, M., Ares, G., \& Hueche, C., (2017). Diet quality, satisfaction with life, family life and food-related life across families: A cross-sectional pilot study with mother-father-adolescent triads. Int. J. Environ. Res. Public Health, 14, pp.1313. 
Schnettler, B., Miranda-Zapata, E., Grunert, K.G., Lobos, G., Denegri, M., Hueche, C., \& Poblete, H. (2017). Life satisfaction of university students in relation to family and food in a developing country. Front. Psychol., 8, pp.1522.

Sivatte, I. d., Gordon, J. R., Rojo, P., \& Olmos, R. (2015). The impact of work-life culture on organizational productivity. Personnel Review, 44(6), pp.883-905.

Spinks, N. (2004). Work-Life Balance: Achievable Goal or Pipe Dream?" The Journal for Quality and Participation, 27(3), pp.4-11.

Strazdins, L., Clements, M.S., Korda, R.J., Broom, D.H., \& D’Souza, R.M., (2006). Unsociable work? Nonstandard work schedules, family relationships, and children's well-being. J. Marriage Fam. 2006, 68, pp.394-410.

The COVID-19 Outbreak: 'Potential Fallout for Sexual and Reproductive Health and Rights', Guttmacher Institute, March 2020

Tomazevic, N., Kozjek, T. \& Stare, J. (2014). The Consequences of a Work-Family (Im) Balance: From the Point of View of Employers and Employees. International Business Research, 7, pp. 83-100.

UK AID, 'Impact of COVID 19 Pandemic on Violence against Women and Girls', 16 March 2020.

UN Women, 'Guidance Note (18 May, 2020) 'Addressing the Impacts of the COVID-19 Pandemic on Women Migrant workers.' https:/www.unwomen.org/en/news/stories/2020/3/statemented- phumzile-COVID-19women-front-and-centre. 